\title{
Selective hydrogenation of 1,3-butadiene in presence of 1-butene under liquid phase conditions with $\mathrm{NiPd} / \mathrm{Al}_{2} \mathrm{O}_{3}$ catalysts
}

\author{
Franklin J. Méndez ${ }^{1,2} \cdot$ Roger Solano $^{3} \cdot$ Yanet Villasana $^{1,4} \cdot$ Julia Guerra $^{5}$. \\ Susana Curbelo $^{5} \cdot$ Marcel Inojosa $^{1} \cdot$ Claudio Olivera-Fuentes $^{5} \cdot$ Joaquín L. Brito $^{1}$
}

Received: 30 September 2015/ Accepted: 18 March 2016/Published online: 2 April 2016

(c) The Author(s) 2016. This article is published with open access at Springerlink.com

\begin{abstract}
The catalytic performance of $\mathrm{Al}_{2} \mathrm{O}_{3}$-supported monometallic and bimetallic catalysts in selective hydrogenation of 1,3-butadiene in the presence of 1-butene under liquid phase conditions was studied. Bimetallic catalysts were prepared by the coimpregnation method with the required amounts of the precursors salts $\left[\mathrm{Ni}\left(\mathrm{NO}_{3}\right)_{2} \cdot 6 \mathrm{H}_{2} \mathrm{O}\right.$ and $\mathrm{Pd}\left(\mathrm{NH}_{3}\right)_{4} \mathrm{Cl}_{2} \cdot \mathrm{H}_{2} \mathrm{O}$ ] over pellet-form $\gamma-\mathrm{Al}_{2} \mathrm{O}_{3}$ with a constant content of $\mathrm{Pd}(0.5 \mathrm{wt} \%)$ and varying $\mathrm{Ni} / \mathrm{Pd}$ atomic ratio $(0.25,0.5,0.75$, and 1$)$ obtaining egg-shell profiles of the active components. The catalysts were characterized by $\mathrm{X}$-ray diffraction, temperature-programmed techniques, such as reduction in hydrogen and desorption of ammonia, $\mathrm{N}_{2}$ physisorption, and transmission electron microscopy. The catalytic test showed that the 1,3-butadiene was selectively hydrogenated when bimetallic catalysts were used. The addition of Ni to the Pd-based catalysts suppressed $n$-butane formation and increased recovery of 1-butene at medium conversion. Therefore, it was observed
\end{abstract}

Franklin J. Méndez

frankmendez.mz@gmail.com

$\checkmark$ Joaquín L. Brito

joabrito@ivic.gob.ve

1 Centro de Química, Instituto Venezolano de Investigaciones Científicas, Apartado Postal 21827, Caracas, Venezuela

2 Present Address: Facultad de Química, Universidad Nacional Autónoma de México, Ciudad De México, Mexico

3 Instituto de Superficies y Catálisis, Universidad del Zulia, Maracaibo, Venezuela

4 Present Address: Cátedra de Química Inorgánica, Universidad Regional Amazónica IKIAM, Tena, Ecuador

5 Departamento de Termodinámica y Fenómenos de Transferencia, Universidad Simón Bolívar, Caracas, Venezuela an improved catalytic performance of the bimetallic catalysts being highest in the case of the $1 \mathrm{NiPd} / \mathrm{Al}_{2} \mathrm{O}_{3}$.

Keywords 1,3-Butadiene $\cdot$ Liquid-phase reactions $\cdot \mathrm{NiPd}$ catalysts $\cdot$ Selective hydrogenation

\section{Introduction}

Alkenes streams produced from cracking processes for use in the petrochemical industry contain small amounts of highly unsaturated hydrocarbons, which cause problems in downstream applications, e.g., because of the oligomerization of such impurities, as 1,3-butadiene (BD) and/or acetylene on the catalyst surface leading to deactivation and increased pressure drop across the catalytic bed. Selective hydrogenation is an effective and economic way of removing these impurities by transforming them into valuable alkenes [1]. This technology employs catalytic fixed beds with cocurrent flow of the liquid hydrocarbons and gaseous hydrogen, operating temperatures ranging from ambient temperature up to around $60-70{ }^{\circ} \mathrm{C}$ and total pressure up to about 200 psi for maintaining the hydrocarbon stream in liquid phase while allowing the desired level of hydrogen partial pressure [2,3].

$\mathrm{Al}_{2} \mathrm{O}_{3}$-supported $\mathrm{Pd}$ or $\mathrm{Pt}$ catalysts are employed in selective hydrogenation of unsaturated carbon-carbon bonds, although Pd-based catalysts are more selective than their Pt-based counterparts in selective hydrogenation of dienes [2]. Nevertheless, either Pt- or Pd-monometallic catalysts give rise to undesirable side reactions, such as the isomerization or total hydrogenation. A way to improve the selectivity consists in including an additive in the process stream [4], e.g., piperidine [5], tributylphosphine [6], diethyl ether [6], carbon monoxide [6, 7], butanethiol [6], 
dimethyl sulfate [6], tert-butyl chloride [6], isoprene [8], and others. However, catalytic performance is more strongly dependent on the transition metals and cometals used as catalysts. Consequently, aiming at minimizing these disadvantages has led to the development of Pd-based bimetallic catalysts, to further improve their selectivity and resistance to deactivation and/or poisoning. In this regard, some researchers have made important modifications to the $\mathrm{Pd} / \mathrm{Al}_{2} \mathrm{O}_{3}$ catalyst [1].

$\mathrm{M}-\mathrm{Pd} / \mathrm{Al}_{2} \mathrm{O}_{3}$ bimetallic catalysts synthesized since 1980 s belong to the so-called third generation. Some researchers have reported significant modifications by the addition of $\mathrm{Cu}$ [9], $\mathrm{Co}$ [10], $\mathrm{Tl}$ [11], $\mathrm{Fe}$ [12, 13], $\mathrm{Ag}$ [12, 14-17], $\mathrm{Au}[12,14,17,18], \mathrm{Sn}$ [19-21], and $\mathrm{Pb}$ [22]. A common characteristic of these bimetallic catalysts is that the second metal decorates the Pd-surface; thus, the decrease in formation of butane (BA) in the bimetallic catalysts could be assigned to diminished diene conversion. Several theoretical and experimental studies have shown that Ni-containing catalysts exhibit excellent activity and selectivity in this reaction [23-27]. Thus, it was reported that $\mathrm{Pd}$ overlayers on the surface of $\mathrm{Ni}$ or Ni-rich $\mathrm{Pd}_{8} \mathrm{Ni}_{92}$ alloy showed much higher activity in the partial hydrogenation of BD than single crystal Pd [28-30]. In a recent theoretical and experimental study, it was also reported a high activity and selectivity of the bimetallic Ni-Pd structures in the selective hydrogenation of BD in the gas phase, both on single crystal model catalysts and on the real alumina supported ones [26]. Even though some work on this type of catalysts has been reported, most of these studies were carried out by quantum-mechanics simulations of the surface, while the reported experimental work usually shows gas-phase reactions, where mass transfer effects cannot be appreciated. To the best of our knowledge, no systematic study of the effect of the Ni-content in bimetallic $\mathrm{NiPd} / \mathrm{Al}_{2} \mathrm{O}_{3}$ catalysts on the selective hydrogenation of $\mathrm{BD}$ in the presence of 1-butene $(\mathrm{BE})$ under liquid phase conditions has been reported. In this sense, the objective of this work is to carry out a preliminary study of the effect of the $\mathrm{Ni} / \mathrm{Pd}$ atomic ratio in $\mathrm{NiPd} / \mathrm{Al}_{2} \mathrm{O}_{3}$ catalysts on some physicochemical properties of the bimetallic catalysts and on their behavior in this reaction of great importance for the petrochemical industry.

\section{Experimental}

For the design of a synthesis protocol, a review of previous studies on the deposition of metallic components on porous supports was necessary [31-33], considering that to inhibit the total hydrogenation toward $\mathrm{BA}$, it is required that the active components must be in an egg-shell profile [34].
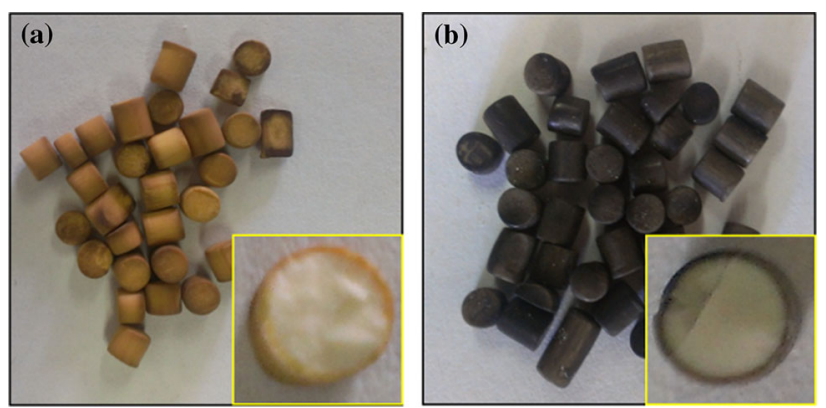

Fig. 1 Photographic images of a typical cross section of a fresh (a) and reduced (b) $1 \mathrm{NiPd} / \mathrm{Al}_{2} \mathrm{O}_{3}$ catalysts

Photographic images of a fresh (Fig. 1a) and reduced (Fig. 1b) catalyst showed that such a required profile was indeed obtained.

\section{Catalysts preparation}

$\mathrm{Al}_{2} \mathrm{O}_{3}$-supported catalysts were prepared by impregnation (monometallic catalysts) or coimpregnation (bimetallic catalysts, $\mathrm{Ni} / \mathrm{Pd}$ atomic ratio from 0.25 to 1 ). In a typical experiment, the required amounts of the precursors salts $\left[\mathrm{Ni}\left(\mathrm{NO}_{3}\right)_{2} \cdot 6 \mathrm{H}_{2} \mathrm{O}\right.$ and/or $\left.\mathrm{Pd}\left(\mathrm{NH}_{3}\right)_{4} \mathrm{Cl}_{2} \cdot \mathrm{H}_{2} \mathrm{O}\right]$ were dissolved in $10 \mathrm{~mL}$ of distilled $\mathrm{H}_{2} \mathrm{O}$. Afterward, each solution was dripped over $\gamma-\mathrm{Al}_{2} \mathrm{O}_{3}$ (cylindrical pellets of $1 / 8^{\prime \prime}$ diameter, previously heat-treated at $120{ }^{\circ} \mathrm{C}$ for $12 \mathrm{~h}$ ). The obtained suspensions were treated under reduced pressure using rotary-evaporation $\left(60{ }^{\circ} \mathrm{C} / 60 \mathrm{rpm}\right)$ until the removal of most of the water was accomplished. The remaining moisture was subsequently eliminated at $60{ }^{\circ} \mathrm{C}$ for $12 \mathrm{~h}$ in dry $\mathrm{N}_{2}$ flow $(100 \mathrm{~mL} / \mathrm{min})$ followed by calcination at $500{ }^{\circ} \mathrm{C}$ for $4 \mathrm{~h}$ under a flow of synthetic air $(100 \mathrm{~mL} / \mathrm{min})$. In all cases, temperature was increased at a linear rate of $3{ }^{\circ} \mathrm{C} / \mathrm{min}$ from room temperature to the final temperature. Monometallic and bimetallic catalysts are denoted by $\mathrm{m} / \mathrm{Al}_{2} \mathrm{O}_{3}$ or $\mathrm{nNiPd} / \mathrm{Al}_{2} \mathrm{O}_{3}$, respectively, where $m$ is the metal nature $(0.3 \mathrm{wt} \% \mathrm{Ni}$ and $0.5 \mathrm{wt} \% \mathrm{Pd})$ and $n$ is the $\mathrm{Ni} /$ $\mathrm{Pd}$ atomic ratio with a Pd-content $0.5 \%$ wt $\%$, e.g., $1 \mathrm{NiPd} /$ $\mathrm{Al}_{2} \mathrm{O}_{3}$ stands for a catalyst supported on $\mathrm{Al}_{2} \mathrm{O}_{3}$ with 0.5 wt\% $\mathrm{Pd}$ and an $\mathrm{Ni} / \mathrm{Pd}$ atomic ratio of 1 .

\section{Physicochemical characterization}

\section{$X$-ray diffraction}

XRD measurements were carried out between 20 and $80 \%$ $2 \theta$ using a BRUKER-SIEMENS D5005 instrument with $\mathrm{Cu}-\mathrm{K} \alpha$ radiation $(\lambda=1.5456 \AA)$, Ni filter, and step rate of $0.02 \%$. Phase identification was made using the JCPDS library [35]. 


\section{Temperature-programmed reduction in hydrogen}

TPR- $\mathrm{H}_{2}$ measurements were carried out in a stainless-steel reaction line coupled to a thermal conductivity detector (TCD). The samples were first placed in a U-shaped quartz reactor and heated up to $120{ }^{\circ} \mathrm{C}$ in $\mathrm{Ar}$ flow $(30 \mathrm{~mL} / \mathrm{min})$ for $2 \mathrm{~h}$ and then cooled down to room temperature. Next, the gas current was changed to a $5 \% \mathrm{H}_{2}$ in Ar mixture, and the temperature was increased to $500{ }^{\circ} \mathrm{C}$, at a heating rate of $10^{\circ} \mathrm{C} / \mathrm{min}$. The water formed during the reduction treatment was collected in a molecular sieve trap at the reactor exit, and the temperature and $\mathrm{H}_{2}$ consumption were registered with a TCD at $6 \mathrm{~s}$ intervals.

\section{Temperature-programmed desorption of ammonia}

TPD- $\mathrm{NH}_{3}$ was performed to estimate the acidity of the catalysts. For this experiment, the sample was placed in a $\mathrm{U}$-shaped quartz reactor and dried at $120^{\circ} \mathrm{C}$ for $2 \mathrm{~h}$ in an Ar flow (30 mL/min). Then, the solid was cooled to $40{ }^{\circ} \mathrm{C}$, and pulses of $\mathrm{NH}_{3} / \mathrm{Ar}\left(0.3 \mathrm{vol} \% \mathrm{NH}_{3}\right)$ were injected up to saturation. Finally, the thermal desorption was carried out from 40 to $500{ }^{\circ} \mathrm{C}$ and registered every $6 \mathrm{~s}$ using a TCD.

\section{Textural properties}

$\mathrm{N}_{2}$ physisorption data were measured with a MICROMERITICS-ASAP 2010 automatic analyzer at liquid $\mathrm{N}_{2}$ temperature. Prior to the experiments, the samples were degassed overnight under vacuum at $60{ }^{\circ} \mathrm{C}$. Specific surface areas were calculated by the Brunauer-Emmett-Teller method $\left(S_{\mathrm{BET}}\right)$, pore volume $\left(V_{\mathrm{p}}\right)$ was determined by $\mathrm{N}_{2}$ adsorption at a relative pressure of 0.98 , and pore size distributions were obtained from the desorption isotherms by means of the Barrett-Joyner-Halenda (BJH) method.

\section{Transmission electron microscopy}

Before of the analysis, samples were dispersed in an ethanol/water mixer and sonicated, then a drop was placed on a $\mathrm{Cu}$ grid covered with $\mathrm{C} /$ collodion. TEM images were obtained in an FEI microscope model TECNAY G2 SPINT BIO-TWIN using an accelerating voltage of $120 \mathrm{kV}$.

\section{Catalytic activity measurements}

\section{Reduction pretreatment}

Prior to starting the activity tests, catalyst samples $(\sim 1 \mathrm{~g})$ were reduced ex situ under $\mathrm{H}_{2}\left(\mathrm{WHSV}=12,000 \mathrm{~h}^{-1}\right)$ within a fixed-bed reactor (U-shaped PYREX ${ }^{\circledR}$ tube $200 \mathrm{~mm}$ in length and $17 \mathrm{~mm}$ in internal diameter). In all cases, the temperature was increased at a linear rate of

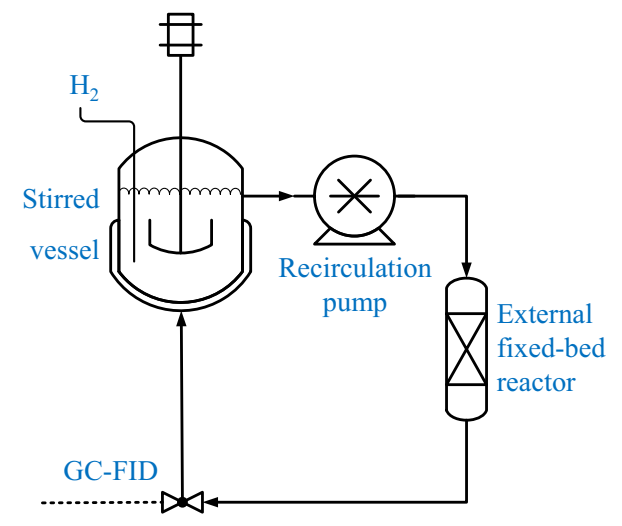

Fig. 2 Recirculation system with external fixed-bed reactor for selective hydrogenation of $\mathrm{BD}$ in the presence of $\mathrm{BE}$

$3{ }^{\circ} \mathrm{C} / \mathrm{min}$ from room temperature to a final temperature of $300{ }^{\circ} \mathrm{C}$, which was held for $2 \mathrm{~h}$. After pretreatment, the samples were cooled to room temperature in $\mathrm{H}_{2}$ and immersed in anhydrous heptane to prevent reoxidation during transport and transferring to the reactor.

\section{Catalytic performance}

The reactivity measurements were carried out in a recirculating system, including an external fixed-bed reactor (Fig. 2) under the following conditions: temperature, $T=40{ }^{\circ} \mathrm{C}$; total pressure, $P=200 \mathrm{psi}$; and weight hourly space velocity, WHSV $=120 \mathrm{~h}^{-1}$. The fixed-bed reactor was a stainless-steel 316 tube with a length $110 \mathrm{~mm}$ in length and $17 \mathrm{~mm}$ internal diameter packed in three sections $(\mathrm{L} 1=$ glass microspheres $/ \mathrm{L} 2=$ catalyst in pellet form $/ \mathrm{L} 3$ = glass microspheres) separated with glass wool plugs. Afterward, this reactor was connected to the reaction system, and the surface was refreshed using a flow of $30 \mathrm{~mL} / \mathrm{min}$ of $\mathrm{H}_{2}$ for $30 \mathrm{~min}$ at the reaction temperature, to remove the protective solvent and expose the active sites. The stirred vessel was fed with $\mathrm{BE}, \mathrm{BD}$, and $\mathrm{H}_{2}$ as reactants, hexane as solvent, and pentane as internal standard, with a volume composition of HX:PA:unsaturated compounds of $73: 2: 25$ and a molar ratio BE:BD of 20:1. The reaction was started by pressurizing with $\mathrm{H}_{2}$ and recirculating the liquid/gas mixture by means of a high pressure pump. Tests were run for at least $180 \mathrm{~min}$.

The effluent stream from the reactor was analyzed with an online gas chromatograph (AGILENT TECHNOLOGIES model GC 6890) equipped with a flame ionization detector and GS-GASPRO capillary column (60-m length and $0.32 \mathrm{~mm}$ internal diameter). The chromatograms were integrated by means of the ChemStation Plus software and converted into mass and mole percentages as recommended by Huang et al. [36]. Furthermore, product selectivities were calculated as mole of product or reactant divided by the total number of mole of feed. 


\section{Results and discussion}

XRD patterns of the support and supported catalysts are shown in Fig. 3. All samples presented some diffraction peaks at $31.9^{\circ}(220), 37.6^{\circ}(311), 39.4^{\circ}(222), 46.1$ (400), 60.1 (511), and 67.1 (440) corresponding to $\gamma-\mathrm{Al}_{2} \mathrm{O}_{3}$ phase (JCPDS card number 10-0425) [35]. However, these samples did not show any diffraction signal corresponding to metallic phases, as $\mathrm{Ni}, \mathrm{NiO}, \mathrm{Pd}, \mathrm{PdO}$, and $\mathrm{Ni}_{\mathrm{x}} \mathrm{Pd}_{\mathrm{y}}$. This is ascribed to the small crystallite size and/or the small amount of the metals over support.

TPR- $\mathrm{H}_{2}$ profiles of the $\mathrm{Al}_{2} \mathrm{O}_{3}$-supported catalysts are shown in Fig. 4. Reduction with hydrogen of the (un-)supported $\mathrm{PdO}$ catalysts is a thermodynamically favored reaction, and it has been found to occur at low temperature $\left(<100{ }^{\circ} \mathrm{C}\right)$ [37]. $\mathrm{Pd} / \mathrm{Al}_{2} \mathrm{O}_{3}$ catalyst presented a low-temperature reduction signal (Fig. 4b), which is ascribed to the reduction of $\mathrm{PdO}$ :

$\mathrm{PdO}+\mathrm{H}_{2} \rightleftharpoons \mathrm{Pd}+\mathrm{H}_{2} \mathrm{O}$.

Some authors have defined three regions for the reduction of the $\mathrm{Al}_{2} \mathrm{O}_{3}$-supported $\mathrm{NiO}$ catalysts [38]: (1) $T_{\mathrm{r}} \leq 450{ }^{\circ} \mathrm{C}$, where support-NiO interaction is weak; (2) $450{ }^{\circ} \mathrm{C} \leq T_{\mathrm{r}} \leq 750{ }^{\circ} \mathrm{C}$, corresponding to strong support$\mathrm{NiO}$ interaction; and (3) $T_{\mathrm{r}} \geq 750{ }^{\circ} \mathrm{C}$, where $\mathrm{NiAl}_{2} \mathrm{O}_{4}$

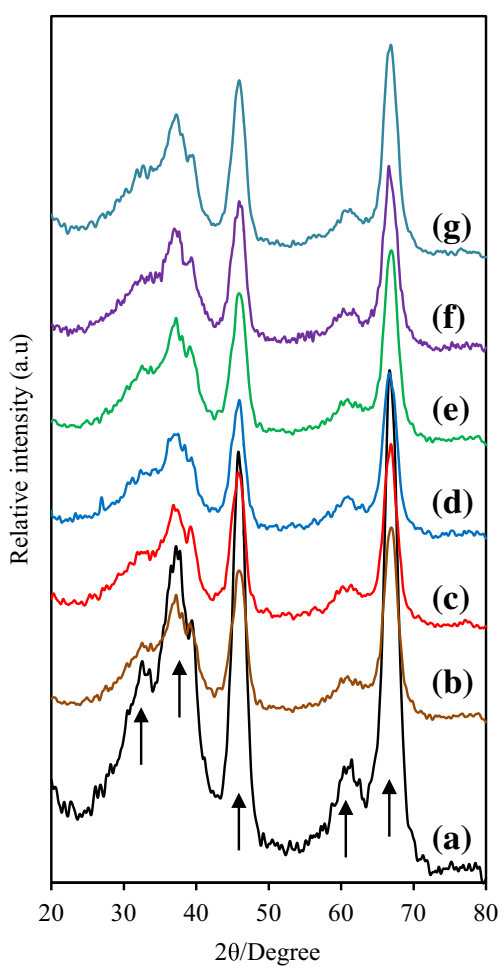

Fig. 3 X-ray diffraction patterns of the supported and monometallic and bimetallic catalysts. a $\mathrm{Al}_{2} \mathrm{O}_{3}, \mathbf{b} \mathrm{Pd} / \mathrm{Al}_{2} \mathrm{O}_{3}(\mathrm{Pd}=0.5 \%$ wt $)$, c $0.25 \mathrm{NiPd} / \mathrm{Al}_{2} \mathrm{O}_{3}$, d $0.5 \mathrm{NiPd} / \mathrm{Al}_{2} \mathrm{O}_{3}$, e $0.75 \mathrm{NiPd} / \mathrm{Al}_{2} \mathrm{O}_{3}$, f $1 \mathrm{NiPd} /$ $\mathrm{Al}_{2} \mathrm{O}_{3}$, and $\mathbf{g ~ N i} / \mathrm{Al}_{2} \mathrm{O}_{3}(\mathrm{Ni}=0.3 \%$ wt $)$

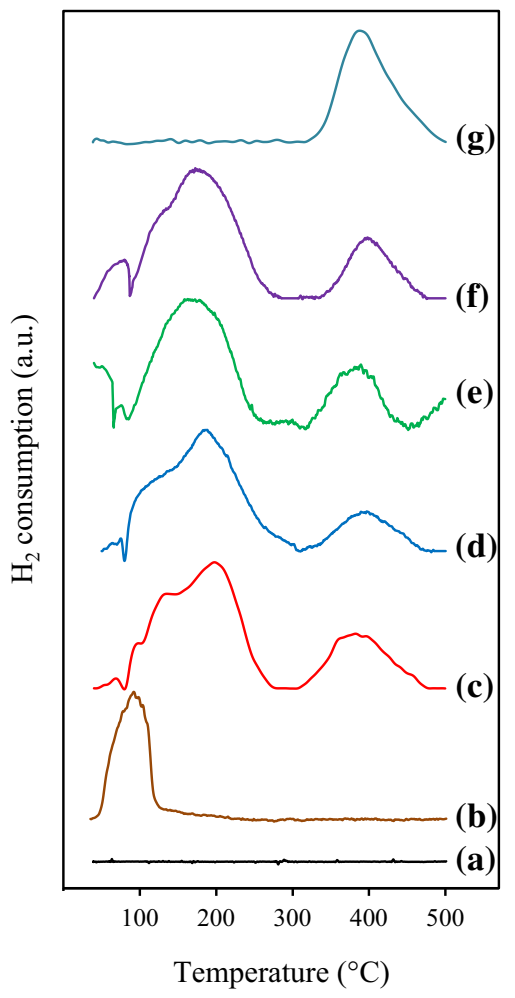

Fig. 4 TPR $-\mathrm{H}_{2}$ profiles of the supported and monometallic and bimetallic catalysts. a $\mathrm{Al}_{2} \mathrm{O}_{3}, \quad$ b $\quad \mathrm{Pd} / \mathrm{Al}_{2} \mathrm{O}_{3} \quad(\mathrm{Pd}=0.5 \%$ wt $)$, c $0.25 \mathrm{NiPd} / \mathrm{Al}_{2} \mathrm{O}_{3}$, d $0.5 \mathrm{NiPd} / \mathrm{Al}_{2} \mathrm{O}_{3}$, e $0.75 \mathrm{NiPd} / \mathrm{Al}_{2} \mathrm{O}_{3}$, f $1 \mathrm{NiPd} /$ $\mathrm{Al}_{2} \mathrm{O}_{3}$, and $\mathbf{g ~ N i} / \mathrm{Al}_{2} \mathrm{O}_{3}(\mathrm{Ni}=0.3 \%$ wt)

reduction occurs. As the catalysts were calcined at $500{ }^{\circ} \mathrm{C}$ and activated by $\mathrm{H}_{2}$ reduction at $300{ }^{\circ} \mathrm{C}$, TPR- $\mathrm{H}_{2}$ experiments were run only up to $500{ }^{\circ} \mathrm{C}$. In agreement with the cited references, $\mathrm{Ni} / \mathrm{Al}_{2} \mathrm{O}_{3}$ presented a broad signal between 300 and $500{ }^{\circ} \mathrm{C}$ (Fig. $4 \mathrm{~g}$ ) that could be attributed to the reduction of weakly interacting $\mathrm{NiO}$ species:

$\mathrm{NiO}+\mathrm{H}_{2} \rightleftharpoons \mathrm{Ni}+\mathrm{H}_{2} \mathrm{O}$.

The position and shapes of both TPR- $\mathrm{H}_{2}$ signals are modified when increasing $\mathrm{Ni}$ content in the $\mathrm{Al}_{2} \mathrm{O}_{3^{-}}$ supported NiPd catalysts. On the other hand, as previously reported by Galiasso and Ravigli-Nasca [39], a group of signals between 100 and $250{ }^{\circ} \mathrm{C}$ (Fig. 4c-f) could be attributed to the formation of a Ni-Pd bimetallic phase. Given the low metal contents, no signals due to Pd, $\mathrm{PdO}, \mathrm{Ni}, \mathrm{NiO}$, or Ni-Pd species were detected by us, and only the diffraction peaks of the support were observed (Fig. 3); signals of the Ni2p and Pd2d core-level spectra obtained by XPS are also weak and noisy (not shown). The obtained TPR $-\mathrm{H}_{2}$ traces allow us to suggest that metallic species should be present, Pd, Ni-Pd alloys, or Ni modified $\mathrm{Pd}$, which must exist after reductive activation. The modifying $\mathrm{Ni}$ species could be partially remain in 


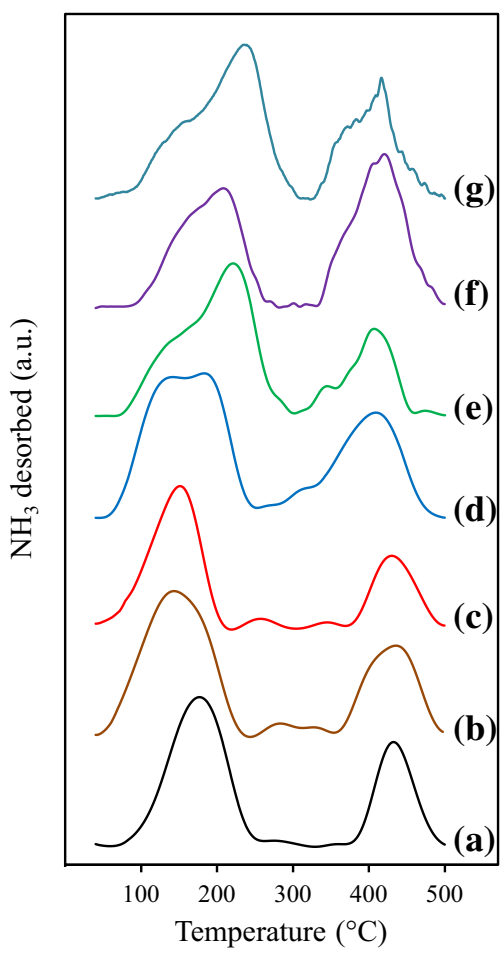

Fig. 5 TPD- $\mathrm{NH}_{3}$ profiles of the supported and monometallic and bimetallic catalysts. a $\mathrm{Al}_{2} \mathrm{O}_{3}, \quad$ b $\quad \mathrm{Pd}_{/} \mathrm{Al}_{2} \mathrm{O}_{3} \quad(\mathrm{Pd}=0.5 \%$ wt $)$, c $0.25 \mathrm{NiPd} / \mathrm{Al}_{2} \mathrm{O}_{3}$, d $0.5 \mathrm{NiPd} / \mathrm{Al}_{2} \mathrm{O}_{3}$, e $0.75 \mathrm{NiPd} / \mathrm{Al}_{2} \mathrm{O}_{3}$, f $1 \mathrm{NiPd} /$ $\mathrm{Al}_{2} \mathrm{O}_{3}$, and $\mathbf{g ~ N i} / \mathrm{Al}_{2} \mathrm{O}_{3}(\mathrm{Ni}=0.3 \%$ wt $)$

unreduced state, as strongly interacting NiO-support and $\mathrm{NiAl}_{2} \mathrm{O}_{4}$ phases have both been reported in samples reduced at low temperatures [38].

TPD- $\mathrm{NH}_{3}$ profiles of the support and $\mathrm{Al}_{2} \mathrm{O}_{3}$-supported $\mathrm{Ni}, \mathrm{Pd}$, and NiPd catalysts are shown in Fig. 5, exhibiting the characteristic two peaks traces that allow to distinguish between weak acid sites plus physisorbed ammonia (low-temperature peak between 40 and $260{ }^{\circ} \mathrm{C}$ ) and strong acid sites (high-temperature peak between 320 and $500{ }^{\circ} \mathrm{C}$ ) [40]. The numbers of strong acid sites present, normalized by the specific area (acid site density), are listed in Table 1. Regarding the acidity measurements, it must be stressed that any effects of the supported metals on these parameters would be limited to the "shell" region of the catalyst pellets, i.e., the "core" region acidbase properties would not be affected. In the TPD-NH results, it can be seen a growth of signal intensity with increasing $\mathrm{Ni} / \mathrm{Pd}$ atomic ratio. These results show that the introduction of $\mathrm{Ni}$ to $\mathrm{Pd} / \mathrm{Al}_{2} \mathrm{O}_{3}$ catalysts generally increases the number of acid sites (Table 1).

A textural analysis was carried out using $\mathrm{N}_{2}$ physisorption techniques, the adsorption-desorption isotherms/pore size distributions and textural properties of the samples are shown in Fig. 6 and Table 1, respectively. First, all samples presented isotherms that could be classified as Type-IV with hysteresis loop Type-H2 according to IUPAC (Fig. 6). This isotherm type is attributed to mesoporous materials, and a hysteresis loop of this kind is characteristic of spheroidal cavities, voids between spherical particles closely packed or ink-bottle-shaped pores. In addition, the hysteresis loop ends at high values of relative pressure $\left(P / P_{0}=0.6-0.7\right)$, which suggests the presence of a high number of large pores (mesopores and/ or macropores). These results are corroborated by the pore size distributions (inset Fig. 6) and average pore size (Table 1) of about $7 \pm 1 \mathrm{~nm}$ in the range of mesopores. Furthermore, in Table 1, it can be seen that $S_{\mathrm{BET}}$ of the catalysts is decreased (by up to about $13 \%$ ) when compared with the support. This effect can be attributed to the partial blockage of the pores, which, likewise, produces a decrease in $V_{\mathrm{p}}$.

Conventional TEM images of the Ni/ $\mathrm{Al}_{2} \mathrm{O}_{3}, \mathrm{Pd} / \mathrm{Al}_{2} \mathrm{O}_{3}$, and $1 \mathrm{NiPd} / \mathrm{Al}_{2} \mathrm{O}_{3}$ catalysts are shown in Fig. $7 \mathrm{a}-\mathrm{c}$, respectively. All catalysts exhibited nanoparticles with pseudospherical morphology. Furthermore, the three catalysts presented a similar particle size, where the majority ( $>90 \%$ of total count) have diameters $<10 \mathrm{~nm}$.

The effect of the increase in the $\mathrm{Ni} / \mathrm{Pd}$ atomic ratio using $\mathrm{Al}_{2} \mathrm{O}_{3}$-supported catalysts was studied by monitoring of the

Table 1 Textural properties and superficial acidity of fresh bimetallic catalysts

\begin{tabular}{|c|c|c|c|c|}
\hline \multirow[t]{2}{*}{ Catalysts } & \multirow{2}{*}{$\begin{array}{l}\text { Surface acidities } \\
\text { Number of strong acid sites } \\
\text { (sites per square nanometer) }\end{array}$} & \multicolumn{3}{|c|}{ Textural properties } \\
\hline & & $S_{\mathrm{BET}}\left(\mathrm{m}^{2} / \mathrm{g}\right)$ & $V_{\mathrm{p}}\left(\mathrm{cm}^{3} / \mathrm{g}\right)$ & $D_{\mathrm{p}}(\mathrm{nm})$ \\
\hline $\mathrm{Al}_{2} \mathrm{O}_{3}$ & 3 & 167 & 0.50 & 7 \\
\hline $\mathrm{Pd} / \mathrm{Al}_{2} \mathrm{O}_{3}$ & 3 & 147 & 0.51 & 7 \\
\hline $0.25 \mathrm{NiPd} / \mathrm{Al}_{2} \mathrm{O}_{3}$ & 3 & 167 & 0.53 & 6 \\
\hline $0.5 \mathrm{NiPd} / \mathrm{Al}_{2} \mathrm{O}_{3}$ & 5 & 155 & 0.51 & 8 \\
\hline $0.75 \mathrm{NiPd} / \mathrm{Al}_{2} \mathrm{O}_{3}$ & 4 & 153 & 0.50 & 6 \\
\hline $1 \mathrm{NiPd} / \mathrm{Al}_{2} \mathrm{O}_{3}$ & 6 & 146 & 0.47 & 7 \\
\hline $\mathrm{Ni} / \mathrm{Al}_{2} \mathrm{O}_{3}$ & 5 & 144 & 0.52 & 7 \\
\hline
\end{tabular}




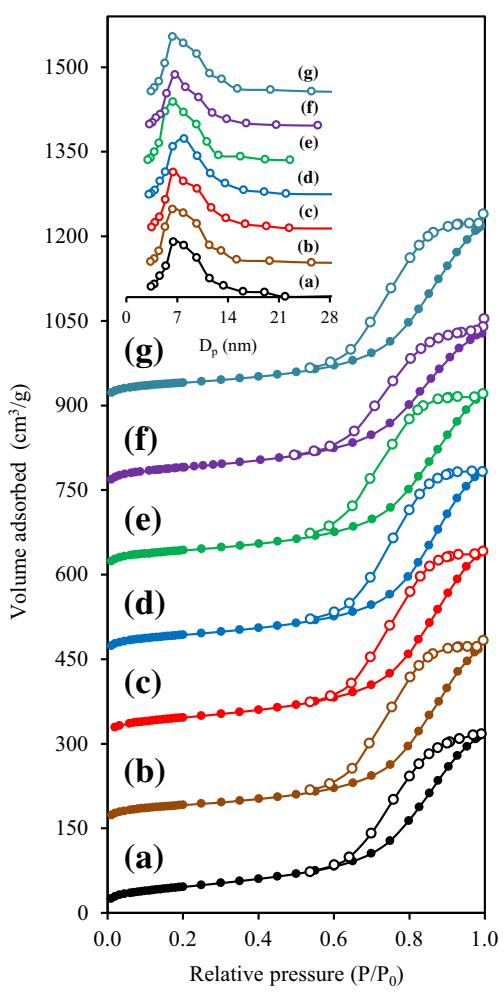

Fig. $6 \mathrm{~N}_{2}$ physisorption isotherms of the supported and monometallic and bimetallic catalysts. a $\mathrm{Al}_{2} \mathrm{O}_{3}, \mathbf{b} \mathrm{Pd} / \mathrm{Al}_{2} \mathrm{O}_{3}(\mathrm{Pd}=0.5 \%$ wt $)$, c $0.25 \mathrm{NiPd} / \mathrm{Al}_{2} \mathrm{O}_{3}$, d $0.5 \mathrm{NiPd} / \mathrm{Al}_{2} \mathrm{O}_{3}$, e $0.75 \mathrm{NiPd} / \mathrm{Al}_{2} \mathrm{O}_{3}$, f $1 \mathrm{NiPd} /$ $\mathrm{Al}_{2} \mathrm{O}_{3}$, and $\mathbf{g ~ N i} / \mathrm{Al}_{2} \mathrm{O}_{3}(\mathrm{Ni}=0.3 \%$ wt). Insets it is shown the pore size distributions

reactants and products in the selective hydrogenation of $\mathrm{BD}$ in the presence of $\mathrm{BE}$ under liquid phase conditions (Fig. 8). As the target of these reactions is to reduce the amount of impurities, with minimal losses of $\mathrm{BE}$ and avoiding the formation of $\mathrm{BA}$, diolefin conversion as a reaction time function (Fig. 9a) and the selectivities to BE (desired product, Fig. 9b) and BA (undesired product, Fig. 9c) as a diolefins conversion function were compared with the $\mathrm{Al}_{2} \mathrm{O}_{3}$-supported monometallic catalysts based on $\mathrm{Ni}$ and $\mathrm{Pd}$.

Interestingly, when NiPd bimetallic catalysts were used, $\mathrm{BD}$ was selectively consumed toward the formation of trans-2-butene (t-BE) and $\mathrm{BE}$ in the first minutes of reaction (Fig. 8b-e). Equally, it was observed that the addition of $\mathrm{Ni}$ does not change the c-BE/t-BE molar ratio but decreases their formation. On the other hand, $\mathrm{Pd} / \mathrm{Al}_{2} \mathrm{O}_{3}$ catalyst yielded a higher conversion of diolefin than $\mathrm{Al}_{2} \mathrm{O}_{3^{-}}$ supported NiPd bimetallic catalysts (Fig. 9a) with a significant loss of BE (Fig. 9b) and the formation of BA (Fig. 9c) at conversions of BD higher than $60 \%$. In contrary, $\mathrm{Ni} / \mathrm{Al}_{2} \mathrm{O}_{3}$ catalyst presented a very low conversion (Fig. 9a). These results indicate that Ni-free catalysts produce a "less selective" reaction under the present
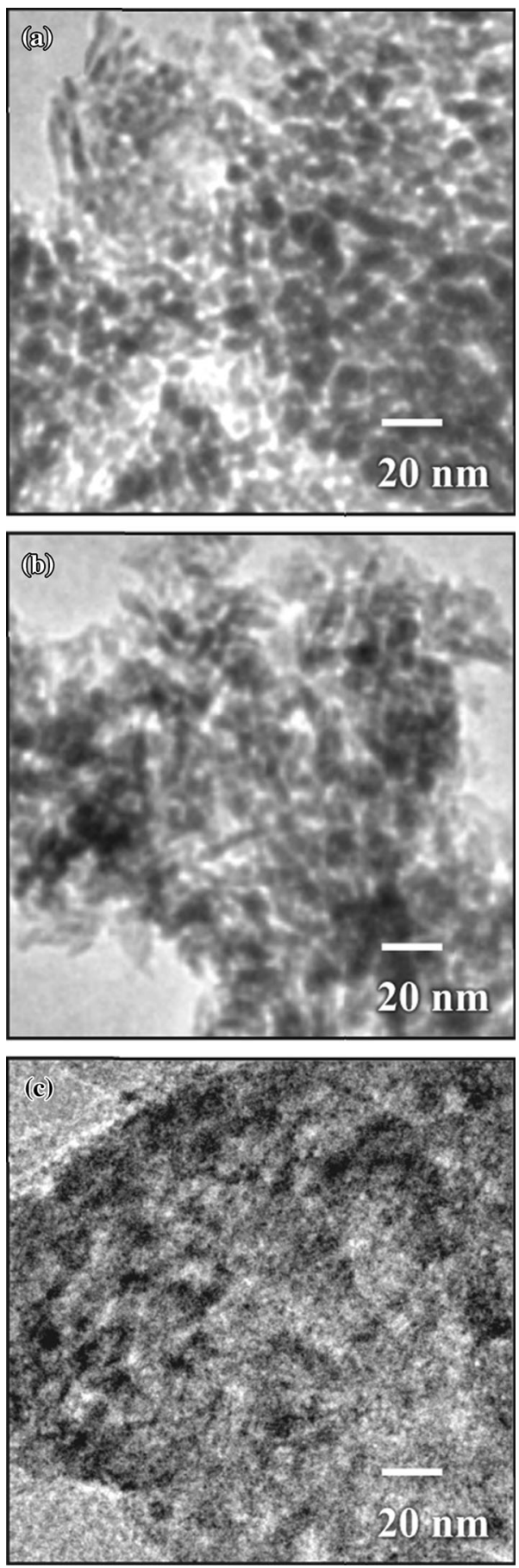

Fig. 7 Representative TEM micrographics of some supported-catalysts. a Ni/ $/ \mathrm{Al}_{2} \mathrm{O}_{3}(\mathrm{Ni}=0.3 \%$ wt $), \mathbf{b} \mathrm{Pd} / \mathrm{Al}_{2} \mathrm{O}_{3}(\mathrm{Pd}=0.5 \%$ wt $)$, and c $1 \mathrm{NiPd} / \mathrm{Al}_{2} \mathrm{O}_{3}$

conditions. Thus, the addition of $\mathrm{Ni}$ produces a positive effect on the catalytic performance of the NiPd bimetallic catalysts, following this trend: $\mathrm{Ni} / \mathrm{Al}_{2} \mathrm{O}_{3}<\mathrm{Pd} / \mathrm{Al}_{2}$ $\mathrm{O}_{3}<0.25 \mathrm{NiPd} / 3 \mathrm{Al}_{2} \mathrm{O}_{3}<0.5 \mathrm{NiPd} / \mathrm{Al}_{2} \mathrm{O}_{3}<0.75 \mathrm{NiPd} /$ $\mathrm{Al}_{2} \mathrm{O}_{3}<1 \mathrm{NiPd} / \mathrm{Al}_{2} \mathrm{O}_{3}$. 
Fig. 8 Products distribution profiles in the selective hydrogenation of 1,3-butadiene in the presence of 1-butene under liquid phase conditions using $\mathrm{Al}_{2} \mathrm{O}_{3}$-supported catalysts. a $\mathrm{Pd} / \mathrm{Al}_{2} \mathrm{O}_{3}$ $(\mathrm{Pd}=0.5 \% \mathrm{wt}), \mathbf{b} 0.25 \mathrm{NiPd} /$ $\mathrm{Al}_{2} \mathrm{O}_{3}$, c $0.5 \mathrm{NiPd} / \mathrm{Al}_{2} \mathrm{O}_{3}$, d $0.75 \mathrm{NiPd} / \mathrm{Al}_{2} \mathrm{O}_{3}$, e $1 \mathrm{NiPd} /$ $\mathrm{Al}_{2} \mathrm{O}_{3}$, and $\mathbf{f ~} \mathrm{Ni} / \mathrm{Al}_{2} \mathrm{O}_{3}$ $(\mathrm{Ni}=0.3 \%$ wt). Reaction conditions: $T=40^{\circ} \mathrm{C}$; $P=200$ psi and $\mathrm{WHSV}=120 \mathrm{~h}^{-1}$
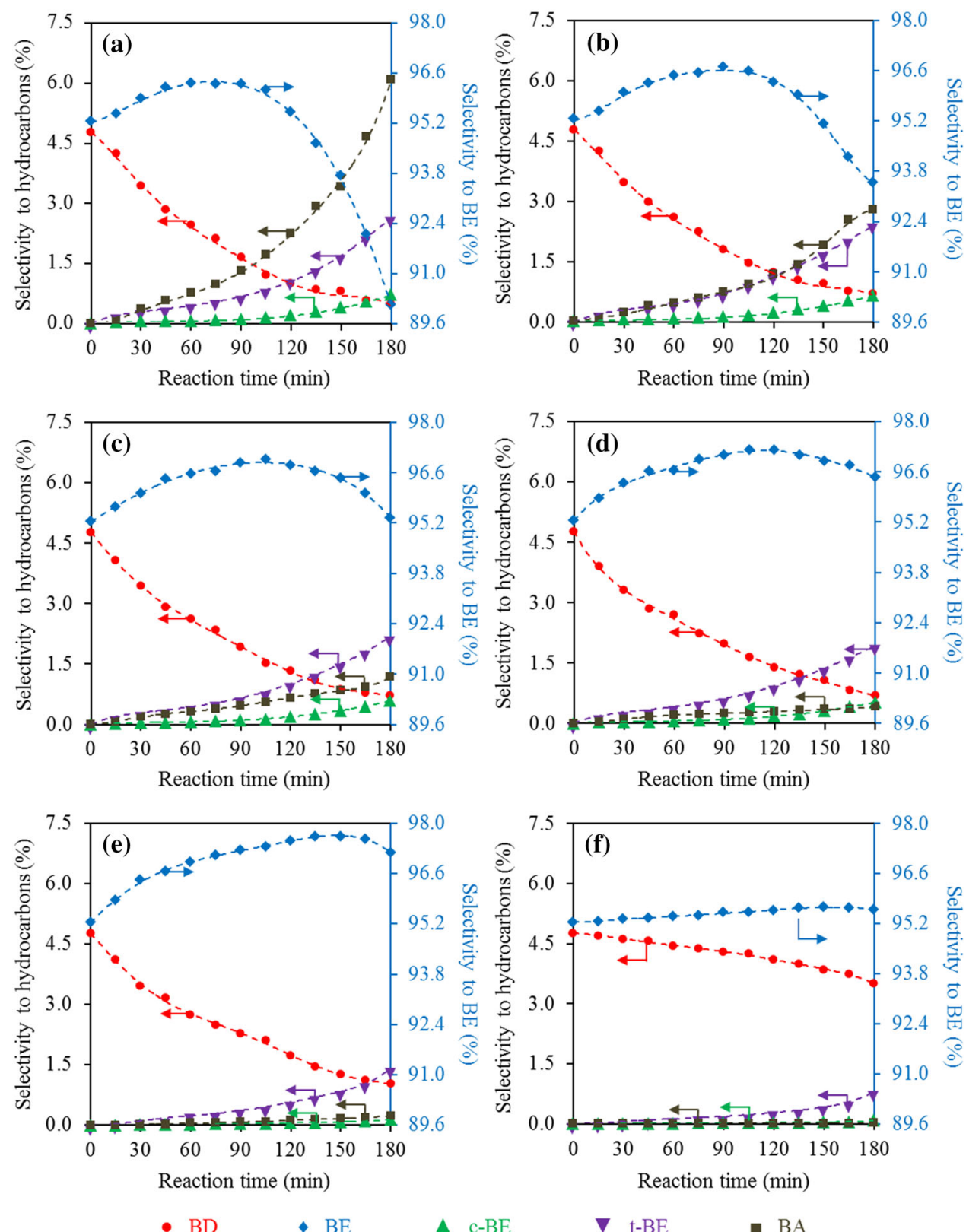

The changes observed with the addition of $\mathrm{Ni}$ to the Pdbased catalysts, i.e., a decrease in the conversion of $\mathrm{BD}$ (Fig. 9a), increase in the selectivity to BE at medium conversions (Fig. 9b), and a decrease in selectivity to BA (Fig. 9c), could be assigned to geometric effect caused by dilution of the Pd atoms due to $\mathrm{Ni}$ addition or formation of a $\mathrm{Ni}-\mathrm{Pd}$ bimetallic alloy that would be formed during reduction at $300{ }^{\circ} \mathrm{C}$ (Fig. 4), and these cause the decrease in the inherent activity of the $\mathrm{Pd}$ atoms when the $\mathrm{Ni} / \mathrm{Pd}$ atomic ratio is incremented; even this beneficial effect has also been observed in an $\mathrm{Al}_{2} \mathrm{O}_{3}$-supported NiPd catalyst $(0.91 \% \mathrm{Pd}$ $1.51 \% \mathrm{Ni} / \gamma-\mathrm{Al}_{2} \mathrm{O}_{3}$, where $\mathrm{Ni} / \mathrm{Pd}$ atomic ratio 3) [26]. This geometric effect causes by dilution together with partial poisoning of Ni-Pd ensembles by firmly held adspecies, as carbonaceous deposits, was previously reported for NiPd/ $\mathrm{SiO}_{2}$ catalysts [24]. However, other authors have proposed another theories to explain these performances that most importantly indicate that: (1) a favorable geometrical arrangement of surface atoms could occur during annealing of Pd atom deposit on $\mathrm{Ni}(111)$, favoring the adsorption of the reactants during hydrogenation [29], (2) a strain relaxation effect of the Ni-Pd surfaces of a Pd monolayer on Ni(110) also could contribute to alkene hydrogenation [41, 42], or (3) self-poisoning or competitive adsorption between BEs and oligomers when $\mathrm{Pd}_{2} \mathrm{Ni}_{50} \mathrm{Nb}_{48}$ ribbon is used as catalysts has also been reported [43]. Equally, additional studies has been 


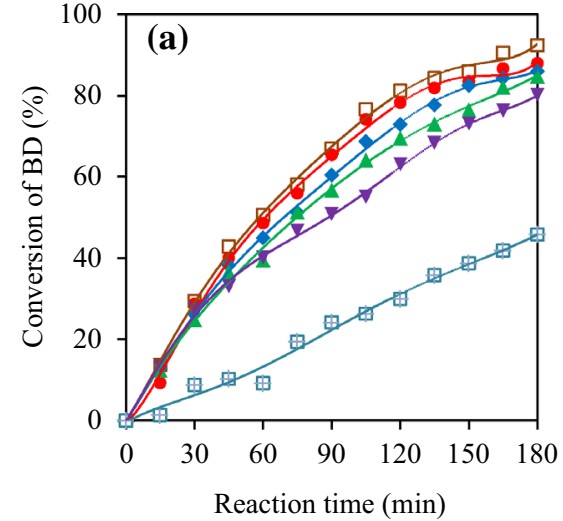

$\square \mathrm{Pd} / \mathrm{Al}_{2} \mathrm{O}_{3} \quad \bullet \quad 0.25 \mathrm{NiPd} / \mathrm{Al}_{2} \mathrm{O}_{3}$

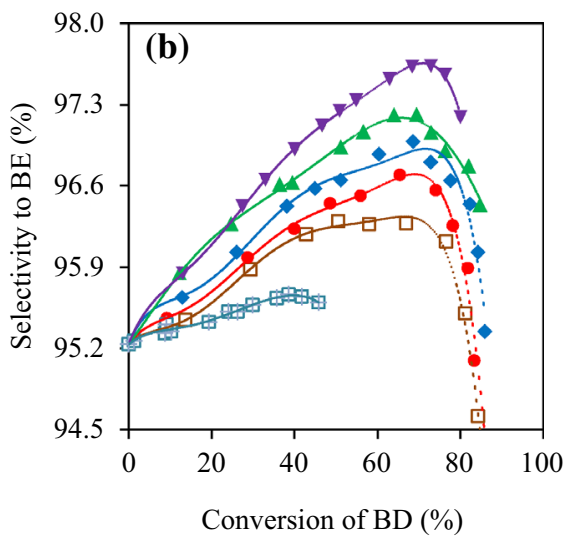

- $0.5 \mathrm{NiPd} / \mathrm{Al}_{2} \mathrm{O}_{3}$

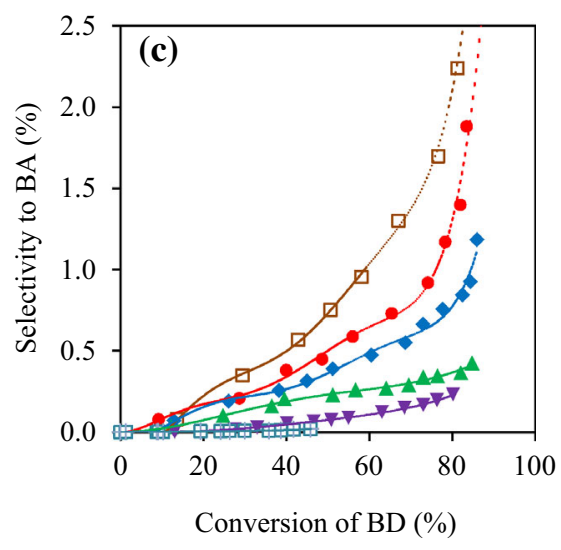

$\boldsymbol{\nabla} 1 \mathrm{NiPd} / \mathrm{Al}_{2} \mathrm{O}_{3} \quad$ \# $\mathrm{Ni} / \mathrm{Al}_{2} \mathrm{O}_{3}$

Fig. 9 Catalytic performance of the catalysts: conversion of BD as a reaction time function (a) and selectivity toward formation of BE (b) and $\mathrm{BA}$ (c) as a diolefins conversion function. Reaction conditions: $T=40^{\circ} \mathrm{C} ; P=200 \mathrm{psi}$; and WHSV $=120 \mathrm{~h}^{-1}$

realized using $\mathrm{Al}_{2} \mathrm{O}_{3}, \mathrm{SiO}_{2}$, or other catalytic supports (or catalytic systems), i.e., $\mathrm{NiPd} / \mathrm{SiO}_{2}[23,44,45], \mathrm{NiPd} / \mathrm{Nb}_{2} \mathrm{O}_{5}$ [43], $\mathrm{Pd} / \mathrm{Al}_{2} \mathrm{O}_{3} / \mathrm{NiAl}$ (100) [46], and $\mathrm{NiPd} / \mathrm{Al}_{2} \mathrm{O}_{3}[25,26]$. However, to the best of our knowledge, there is not published research on the changes of Ni-content in Pd-catalysts supported on $\mathrm{Al}_{2} \mathrm{O}_{3}$ and their behavior in similar reactions.

\section{Conclusions}

A series of $\mathrm{Pd}$-based catalysts promoted with various amounts of $\mathrm{Ni}$ for the selective hydrogenation of 1,3-butadiene in the presence of 1-butene under liquid phase conditions were investigated in a recirculation system with external fixed-bed reactor at $40{ }^{\circ} \mathrm{C}$ and a total pressure of 200 psi. The most important results showed that the increase in $\mathrm{Ni} / \mathrm{Pd}$ atomic ratio suppressed $n$-butane formation at relatively long contact time, increasing the recovery of 1-butene at middle conversion of 1,3-butadiene. The $1 \mathrm{NiPd} / \mathrm{Al}_{2} \mathrm{O}_{3}$ catalyst $(\mathrm{Pd}=0.5 \mathrm{wt} \%$ and $\mathrm{Ni} / \mathrm{Pd}$ atomic ratio $=1$ supported on $\gamma-\mathrm{Al}_{2} \mathrm{O}_{3}$ ) presented the best catalytic performance. A dilution effect caused by $\mathrm{Ni}-\mathrm{Pd}$ alloy formation could explain the beneficial influence on the catalytic activity for this reaction of great importance in the petrochemical industry.

Acknowledgments The authors would like to acknowledge financial support by Fondo Nacional de Ciencia, Tecnologia e Innovación (FONACIT) through Project G-2005000437. FJM personally expresses thanks to FONACIT: Science Mission Program for providing granting a scholarship for $\mathrm{PhD}$ studies.

Open Access This article is distributed under the terms of the Creative Commons Attribution 4.0 International License (http:// creativecommons.org/licenses/by/4.0/), which permits unrestricted use, distribution, and reproduction in any medium, provided you give appropriate credit to the original author(s) and the source, provide a link to the Creative Commons license, and indicate if changes were made.

\section{References}

1. Méndez FJ, Villasana Y, Guerra J, Sifontes AB, Olivera-Fuentes C, Brito JL (2012) Aspectos relevantes de la hidrogenación selectiva de 1,3-butadieno con catalizadores basados en $\mathrm{Pd} /$ $\mathrm{Al}_{2} \mathrm{O}_{3}$. Catálisis 1:48-69

2. Derrien ML (1986) Selective hydrogenation applied to the refining of petrochemical raw materials produced by steam cracking. Stud Surf Sci Catal 27:613-666

3. Alves JA, Bressa SP, Martínez OM, Barreto GF (2013) Kinetic evaluation of the set of reactions in the selective hydrogenation of 1-butyne and 1,3-butadiene in presence of n-butenes. Ind Eng Chem Res 52:5849-5861

4. Boitiaux JP, Cosyns J, Martino G (1982) Additives effects in the selective hydrogenation of unsaturated hydrocarbons. Stud Surf Sci Catal 11:355-368

5. Boitiaux JP, Cosyns J, Robert E (1989) Additive effects in the selective hydrogenation of unsaturated hydrocarbons on platinum and rhodium catalysts. Part I: influence of nitrogen-containing compounds. Appl Catal 49:219-234

6. Boitiaux JP, Cosyns J, Robert E (1989) Additive effects in the selective hydrogenation of unsaturated hydrocarbons on platinum and rhodium catalysts. Part II: influence of various compounds containing phosphorus, oxygen, sulphur and chlorine on the catalytic performance of platinum catalyst. Appl Catal 49:235-246

7. Silvestre-Albero J, Rupprechter G, Freund HJ (2005) Atmospheric pressure studies of selective 1,3-butadiene hydrogenation on Pd single crystals: effect of CO addition. J Catal 235:52-59

8. Alves JA, Bressa SP, Martínez OM, Barreto GF (2004) Selective hydrogenation of 1,3-butadiene: improvement of selectivity by using additives. Chem Eng J 99:45-51

9. Furlong BK, Hightower JW, Chan TYL, Sarkany A, Guczi L (1994) 1,3-Butadiene selective hydrogenation over Pd/alumina and $\mathrm{CuPd} /$ alumina catalysts. Appl Catal A 117:41-51

10. Sarkany A, Zsoldos Z, Stefler G, Hightower JW, Guczi L (1995) Promoter effect of Pd in hydrogenation of 1,3-butadiene over CoPd catalysts. J Catal 157:179-189 
11. Ohnishi R, Suzuki H, Ichikawa M (1995) Selectivity controlling in the hydrogenation of 1,3-butadiene on Tl-modified Pd catalyst. Catal Lett 33:341-348

12. Miura H (1996) Preparation of supported bimetallic catalysts by means of selective deposition using mobile metal compounds as precursors. Catal Today 28:215-221

13. Crabb EM, Marshall R (2001) Properties of alumina supported $\mathrm{Pd}-\mathrm{Fe}$ and Pt-Fe catalysts prepared using surface organometallic chemistry. Appl Catal A 217:41-53

14. Miura H, Terasaka M, Oki K, Matsuda T (1993) Preparation of egg-shell type Pd-Ag and Pd-Au catalysts by selective deposition and hydrogenation of 1,3-butadiene. Stud Surf Sci Catal 75:2379-2382

15. Sarkany A (1997) Self-poisoning and aging of $\mathrm{Pd}-\mathrm{Ag} / \mathrm{Al}_{2} \mathrm{O}_{3}$ in semi-hydrogenation of 1,3-butadiene: effects of surface inhomogeneity caused by hydrocarbonaceous deposits. Stud Surf Sci Catal 111:111-118

16. Sarkany A (1997) Semi-hydrogenation of 1,3-butadiene over Pd$\mathrm{Ag} / \alpha-\mathrm{Al}_{2} \mathrm{O}_{3}$ poisoned by hydrocarbonaceous deposits. Appl Catal A 165:87-101

17. Redjala T, Remita H, Apostolescu G, Mostafavi M, Thomazeau C, Uzio D (2006) Bimetallic Au-Pd and Ag-Pd clusters synthesised by $\gamma$ or electron beam radiolysis and study of the reactivity/ structure relationships in the selective hydrogenation of buta-1,3diene. Oil Gas Sci Technol 61:789-797

18. Hugon A, Delannoy L, Krafft JM, Louis C (2010) Selective hydrogenation of 1,3-butadiene in the presence of an excess of alkenes over supported bimetallic gold-palladium catalysts. J Phys Chem C 114:10823-10835

19. Choi SH, Lee JS (2000) XAFS study of tin modification of supported palladium catalyst for 1,3-butadiene hydrogenation in the presence of 1-butene. J Catal 193:176-185

20. Verdier S, Didillon B, Morin S, Uzio D (2003) Pd-Sn/ $/ \mathrm{Al}_{2} \mathrm{O}_{3}$ catalysts from colloidal oxide synthesis. Parte II: surface characterization and catalytic properties for buta-1,3-diene selective hydrogenation. J Catal 218:288-295

21. Pattamakomsan K, Ehret E, Morfin F, Gélin P, Jugnet Y, Prakash S, Bertolini JC, Panpranot J, Aires FJCS (2011) Selective hydrogenation of 1,3-butadiene over Pd and Pd-Sn catalysts supported on different phases of alumina. Catal Today 164:28-33

22. Goetz J, Volpe MA, Gigola CE, Touroude R (2001) Low-loaded $\mathrm{Pd}-\mathrm{Pb} / \mathrm{\alpha}-\mathrm{Al}_{2} \mathrm{O}_{3}$ Catalysts: effect of alloying in the hydrogenation of buta-1,3-diene and hydrogenation and isomerization of butenes. J Catal 199:338-345

23. Renouprez A, Faudon JF, Massardier J, Rousset JL, Delichère $P$, Bergeret G (1997) Properties of supported Pd-Ni catalysts prepared by coexchange and organometallic chemistry. Part II: correlation between the reactivity for butadiene hydrogenation and the surface properties studied by XPS and LEIS. J Catal 170:181-190

24. Sarkany A (2000) Promoting effect of Ni in semi-hydrogenation of 1,3-butadiene over Ni-Pd catalysts. Stud Surf Sci Catal 130:2081-2086

25. Massard R, Uzio D, Thomazeau C, Pichon C, Rousset JL, Bertolini JC (2007) Strained Pd overlayers on Ni nanoparticles supported on alumina and catalytic activity for buta-1,3-diene selective hydrogenation. J Catal 245:133-143

26. Hou R, Yu W, Porosoff MD, Chen JG, Wang T (2014) Selective hydrogenation of 1,3-butadiene on PdNi bimetallic catalyst: from model surfaces to supported catalysts. J Catal 316:1-10

27. Gómez G, Belelli PG, Cabeza GF, Castellani NJ (2015) A theoretical view of 1,3-butadiene selective hydrogenation toward cis-2-butene on PdNi layered catalyst. Appl Surf Sci 353:820-828

28. Saint-Lager MC, Jugnet Y, Dolle P, Piccolo L, Baudoing-Savois R, Bertolini JC, Bailly A, Robach O, Walker C, Ferrer S (2005)
$\mathrm{Pd}_{8} \mathrm{Ni}_{92}(100)$ surface structure from surface X-ray diffraction: surface evolution under hydrogen and butadiene reactants at elevated pressure. Surf Sci 587:229-235

29. Hermann P, Tardy B, Simon D, Guigner JM, Bigot B, Bertolini JC (1994) Catalytic properties of Pd atom deposit on $\mathrm{Ni}(111)$. Surf Sci 307-309:422-427

30. Hermann P, Guigner JM, Tardy B, Jugnet Y, Simon D, Bertolini JC (1996) The Pd/Ni(110) bimetallic system: surface characterisation by LEED, AES, XPS, and LEIS techniques: New insight on catalytic properties. J Catal 163:169-175

31. Brunelle JP (1978) Preparation of catalysts by metallic complex adsorption on mineral oxides. Pure Appl Chem 50:1211-1229

32. Lekhal A, Glasser BJ, Khinast JG (2001) Impact of drying on the catalyst profile in supported impregnation catalysts. Chem Eng Sci 56:4473-4487

33. Lekhal A, Glasser BJ, Khinast JG (2004) Influence of pH and ionic strength on the metal profile of impregnation catalysts. Chem Eng Sci 59:1063-1077

34. Ardiaca NO, Bressa SP, Alves JA, Martínez OM, Barreto GF (2001) Experimental procedure for kinetic studies on egg-shell catalysts: the case of liquid-phase hydrogenation of 1,3-butadiene and n-butenes on commercial Pd catalysts. Catal Today 64:205-215

35. International Center for Diffraction Data, PCPDFWIN v.2.02. PDF-2 Data Base, Newtown Philadelphia, 1995

36. Huang Y, Ou Q, Yu W (1990) Characteristics of flame ionization detection for the quantitative analysis of complex organic mixtures. Anal Chem 62:2063-2064

37. Chou CW, Chu SJ, Chiang HJ, Huang CY, Lee CJ, Sheen SR, Perng TP, Yeh CT (2001) Temperature-programmed reduction study on calcination of nano-palladium. J Phys Chem B 105:9113-9117

38. Chen SL, Zhang HL, Hu J, Contescu C, Schwarz JA (1991) Effect of alumina supports on the properties of supported nickel catalysts. Appl Catal 73:289-312

39. Galiasso-Tailleur R, Ravigli-Nascar J (2012) Effect of $\mathrm{H}_{2} \mathrm{~S}$ on selective hydrogenation of diolefins using $\mathrm{NiPdCe}(\mathrm{x}) / \mathrm{Si}-\mathrm{Al}-$ coated structured packing catalyst. Appl Catal A 439-440:125-134

40. Falconer JL, Schwarz JA (1983) Temperature-programmed desorption and reaction: applications to supported catalysts. Catal Rev 25:141-227

41. Filhol JS, Simon D, Sautet P (2001) Stress induced nanostructure in a Pd monolayer on $\mathrm{Ni}(110)$ : a first principles theoretical study. Surf Sci 472:L139-L144

42. Filhol JS, Simon D, Sautet P (2004) Understanding the high activity of a nanostructured catalyst obtained by a deposit of Pd on Ni: first Principle Calculations. J Am Chem Soc 126:3228-3233

43. Sarkany A, Schay Z, Stefler G, Borkó L, Hightower JW, Guczi L (1995) Hydrogenation of 1,3-butadiene over catalysts prepared from amorphous $\mathrm{Pd}_{2} \mathrm{Ni}_{50} \mathrm{Nb}_{48}$ ribbon: effect of self-poisoning on competitive adsorption. Appl Catal B 124:L181-L187

44. Nakagawa Y, Tomishige K (2010) Total hydrogenation of furan derivatives over silica-supported Ni-Pd alloy catalyst. Catal Comm 12:154-156

45. Faudon JF, Senocq F, Bergeret G, Moraweck B, Clugnet G, Nicot C, Renouprez A (1993) Properties of supported Pd-Ni catalysts prepared by coexchange and by organometallic chemistry. Part I: preparation and characterization by X-ray-diffraction, analytical microscopy, and EXAFS. J Catal 144:460-471

46. Silvestre-Albero J, Rupprechter G, Freund HJ (2006) Atmospheric pressure studies of selective 1,3-butadiene hydrogenation on well-defined $\mathrm{Pd} / \mathrm{Al}_{2} \mathrm{O}_{3} / \mathrm{NiAl}(110)$ model catalysts: effect of $\mathrm{Pd}$ particle size. J Catal 240:58-65 